\title{
28 Research Soure \\ GIS-Based Flood Hazard Mapping in Itang District of the Gambella Region, Ethiopia
}

\section{Dame Tadesse}

Addis Ababa University

Venkata Suryabhagavan Karuturi ( $\nabla$ drsuryabhagavan@gmail.com )

Addis Ababa University https://orcid.org/0000-0003-2528-9106

Dessie Nedaw

Addis Ababa University

\section{Research}

Keywords: Analytic hierarchy process, Frequency factor, Flood hazard zone, Gumbel distribution

Posted Date: April 27th, 2021

DOI: https://doi.org/10.21203/rs.3.rs-430787/v1

License: (1) This work is licensed under a Creative Commons Attribution 4.0 International License.

Read Full License 
GIS-based flood hazard mapping in Itang District of the Gambella Region, Ethiopia Dame Tadesse, K. V. Suryabhagavan* and Dessie Nedaw School of Earth Sciences, Addis Ababa University, P.O. Box 1176, Addis Ababa, Ethiopia *Corresponding Author: E-mail: drsuryabhagavan@gmail.com

Tel.: +251-911998588 


\title{
GIS-based flood hazard mapping in Itang District of the Gambella Region, Ethiopia
}

\begin{abstract}
Flood is one of the natural disasters that affect societies around the world. Every year, flood claims hundreds of human lives and causes damage to the global economy and environment. Consequently, the identification of flood-vulnerable areas is important for comprehensive flood risk management. This study aims to delineate flood hazard areas in Itang District of Gambella Region, Ethiopia, applying the Gumbel probability distribution and Analytical Hierarchy Process (AHP) method. Distribution models applied in the study involve the generalized extreme value, Gumbel, Log-Normal, and Log Pearson type III. The Gumbel distribution provides the best fit according to the extreme value analyses. After obtaining discharge level through the method, the region's flood inundation area was mapped at 5, 10, 25, 50, and 100-year recurrence intervals. The developed methodology processes six parameters, namely, slope, elevation, land-use/land-cover, rainfall, discharge, and soil. Each criterion was evaluated with the aid of AHP and mapped by GIS. Data were assorted into five suitability classes, viz., very high, high, moderate, low, and very low flooding areas, representing $29.7 \%, 27.8 \%, 18.5 \%, 12.7 \%$, and $11.4 \%$, respectively. The outcome is extremely useful for evacuation planning, damage assessment, and losses estimation, thereby minimizing the natural disaster's effect in the study area.
\end{abstract}

Keywords: Analytic hierarchy process, Frequency factor, Flood hazard zone, Gumbel distribution 


\section{Introduction}

Flood is one of the major natural hazards, often with enormous impact affecting 170 million people annually worldwide (Kowalzig 2008; Guthrie and Cuervo 2015; Mezgebedingil and Suryabhagavan 2018). According to the available data from 1900 to 2013, floods have caused 7 million deaths and US \$600 billion losses (Deng and Zhou 2013). Moreover, flooding events are expected to increase in frequency and intensity in the coming years due to rising sea levels and climate change (IPCC 2007, 2012; UNISDR 2009; Jonathan et al. 2013; Stijn et al. 2013). Therefore, determinations of optimum strategies are essential for appropriate flood management (Ballesteros-Cánovas et al. 2013).

Occurrence of the flood is a very complex phenomenon that always attracted researchers from different parts of the world to understand and explore its prevention and management mechanisms. Among anthropogenic factors triggering floods is increasing deforestation resulting from population pressure. Ethiopia receives maximum summer rainfall between June-August and leading to disastrous floods in some parts of the country (Abebe Feyisa 2007; Alemu 2015; Getahun and Gebre 2015; Amare and Okubay 2019). The Gambella region of Ethiopia experiences flood events almost every year, generally during the monsoon seasons (June-September). Over the last decade itself, many disastrous floods that affected human lives, property, agriculture, and other infrastructure; have occurred in the region. According to the most recent report from UNICEF (September 2017), floods affected more than 53,000 people in Gambella and Oromia regions during August and September, 2017. The most devastating flood events have been recorded in the years 2006, 2007, 2010, 2011, and 2012 (Haile et al. 2013). Bryan et al. (2009) reported that climate change had intensified the spatiotemporal variability of rainfall, which posed serious threats to the local communities in the form of floods. In addition, complex topography of the region coupled with fragile socioeconomic conditions of the locals aggravated flood risk (Mezgebedingil and Suryabhagavan 2018; Wang et al. 2019). These incidences are more intense in developing countries, with rapid urbanization and civilization along the rivers. Removal forests to build settlements and modify of river courses are common practices in such regions, where such acts work as catalyst to flood occurrence (Bronstert 2003; World Bank 2010).

In flood assessments, estimation concerning the associated flood hazard and risk in terms of intensity, magnitude, and spatial/temporal distribution are of vital importance (Shrestha and Lohpaisankrit 2017; Tehrany et al. 2013, 2017; Hong et al. 2018a). Over the past few decades, numerous methods have been developed and used to investigate flood hazards and risk assessment. However, any accurate prediction of the flood-prone areas is considered a difficult task due mainly to the complex and dynamic nature of floods ((Rozalis et al. 2010; Kia et al. 2012; Chapi et al. 2017; Hong et al. 2018a). Classifying the existing models used in this hydrological phenomenon and the phases involved in the cycle, Devi et al. (2015) distinguished them as empirical, conceptual, and physical models. According to the authors, empirical models are observation-oriented based on data and mathematical formulas. Most of the recent models mainly focused on hydrological models, hydrodynamic models, multi-criteria decision analysis (MCDA), statistical models (SM), and machine learning (ML) techniques incorporated into geographical information system (GIS) (Lee et al. 2012; Elsafi 2014; Tehrany et al. 2014a; Yang et al. 2014; Danumah et al. 2016; de Brito and Evers 2016; Rahmati et al. 2016c; Rao 2017; Shafapour Tehrany et al. 2017; Luu et al. 2018; Feloni et al. 2020). Remote sensing and GIS tools are 
also important and have been used extensively for hazard assessment (Islam and Sado 2000a; Fernández and Lutz 2010; Kia et al. 2012; Ashley et al. 2014; Tehrany et al. 2014b; Barua et al. 2016). Studies have revealed that MCDA models are better suited for flood assessment. AHP is a popular model in the field of MCDA, because it can solve complex decision problem without any data (Fernández and Lutz 2010; Danumah et al. 2016; Gigovi et al. 2017; Samela et al. 2018; Morea and Samanta 2020).

Over the last two decades, remote sensing has played an increasing role in water resource management (Dewan et al. 2007; Winsemius et al. 2013; Mina and Ying 2015). Geographic Information System (GIS) is also used extensively to model surface water and flood damage assessment (Opolot 2013; Santillan et al. 2016; Rimba et al. 2017; Ogato et al. 2020). The Hydrologic Engineering Center's River Analysis System (HEC-RAS) model developed by the U.S. Army Corps of Engineers (USACE) is generally used for investigating flooding and flood-related hazards worldwide (Smith and Ward 1998; U.S.Corps of Engineers 2002; Merz et al. 2004; Brunner 2016; Azouagh et al. 2018). The present study was taken up to delineate flood zones and prepare flood hazard maps of the vulnerable areas of Itang District in Gambella Region of Ethiopia by integrating remote sensing, GIS, and hydraulic simulation model, HEC-RAS.

\section{Materials and methods}

\subsection{Study area}

This study was conducted in the Itang District of the Gambella Region, located in the southwestern part of Ethiopia. Geographically it is situated between $08^{\circ} 00^{\prime} 00^{\prime \prime}-08^{\circ} 45^{\prime} 00^{\prime \prime} \mathrm{N}$ latitude and $34^{\circ} 00^{\prime} 00^{\prime \prime}-34^{\circ} 30^{\prime} 00^{\prime \prime} \mathrm{E}$ longitude covering a total area of $2190.42 \mathrm{~km}^{2}$ (Fig. 1). Elevation of the region ranges from $385.5-705.5 \mathrm{~m}$ asml. Annual rainfall ranges between 239.2 and $1883.7 \mathrm{~mm}$ with precipitation throughout the year, but mostly $85 \%$ between May and October. Average annual temperature in the region is $27.5^{\circ} \mathrm{C}$. The Itang Special District encompasses 21 villages, most of which are situated in the flood plain zones of Baro river, the widest in Ethiopia. The study area experienced disastrous floods in 2006, 2007, 2010, 2011, and 2012 with adverse impacts on people's lives, property, agriculture, and infrastructure (Haile et al. 2013). During the summer season, heavy rainfall causes floods in the region, and sometimes the monsoon's unusual activity causes high surface run-off with peak discharge.

\subsection{Data and Methods}

Spatial inputs such as topographic data that include DEM, satellite image, and hydrologic data covering discharge and population data were used for this study. Recent highly accurate topographic data were utilized. Rainfall data were collected from National Meteorological Agency (NMA), Ethiopia. Landsat 8 Operational Land Imager (OLI) satellite data of 2017 with path171and row 054 were downloaded from United States Geological Survey (USGS, https://glovis.usgs.gov). Digital elevation model (DEM) data with spatial resolution of $30 \mathrm{~m}$ were also obtained from the same source. The slope layer was extracted from DEM. Details of the data sources and their specifications are mentioned in Table 1. The satellite image was projected in UTM projection zone $36 \mathrm{~N}$ and Adindan datum. In the present study, ERDAS Imagine, ArcGIS and ArcHydro software were used for flood hazard analysis. HEC-GeoRAS pre-processing was then completed, and the final output from the ArcGIS, and HEC-GeoRAS was processed in the HEC-RAS 1D steady flow simulation. Overall methodological framework and data analysis is presented in Fig. 2. 


\subsection{Field data and sampling}

Land-use/land-cover information was obtained from the multiband Landsat imagery through image interpretation and classification ( $\mathrm{Li}$ et al. 2014). A total of eight land-use/land-cover classes, namely, cropland, woodland, grassland, wetland, forest, shrubland, settlement, and water body, were identified as proposed by Anderson et al. (1976). With the complementary use of satellite navigation system (GPS), post-classification field visits were performed for ground validation of ambiguous spots and further refinement of the landuse/land-cover classification. Training flood locations (150 points) were selected randomly to produce dependent data, which was made up of 0 and 1 values, with 1 representing the existence of flood and 0 its absence of flooding. Additionally, the same numbers of points (150) as flood locations were selected as nonflooded areas with an assigned value of 0 .

\subsection{Flood frequency analysis from hydrologic data}

Database on past floods is important to the study of the relationship between different flood triggering factors and their occurrence (Kia et al. 2012; Merz et al. 2014). Flood frequency analysis is a statistical measure of the probable occurrence of the flood of a given magnitude. The probability of occurrence for the large and destructive floods is low compared to small and less destructive ones. Moreover, the accuracy of the flood susceptibility mapping greatly relies on the accuracy of previous flood events (Merz et al. 2014). It is possible to calculate probability of major and destructive floods in terms of stream water discharge for a specified time (Khosravi et al. 2016). As indicated in the flowchart, two flood frequency methods, namely, Gumbel distribution and Log Pearson Type III, were used for the study. The choice of these methods was based on two cogent reasons. The first is the lack of appropriate river runoff data, which makes it inevitable to utilize the most ecologically and hydrologically fit measure. The second is to provide a suitable hydrologic inundation procedure that will generate the actual water level threshold for flood mapping purposes (Subramanya 2008).

\section{Gumbel distribution}

First introduced in 1914 by Gambel, this is the most common and widely known probability analysis, especially in meteorological and hydrological studies related to flood predictions. Gumbel defined flood as the largest of the 365 daily flows. The annual series of flood flows constitute a chain of the largest values of flows. In this study, an attempt was made to compute water levels at 5, 10, 25, 50, and 100 return periods. Gumbel's equation is given as:

$\mathrm{X}_{\mathrm{T}}=X \mathrm{avg}+\mathrm{K}^{*} \mathrm{STDV}$

where $X_{T}$ stands for the value of variate with a return period 'T', $X$ avg for mean of the variate, STDV for standard deviation of the sample, $K$ for frequency factor expressed as $K=\mathrm{Y}_{\mathrm{T}}-\mathrm{Yn} / \mathrm{Sn}$ or $=\mathrm{Y}_{\mathrm{T}}-0.577 / 1.2825$ with $\mathrm{Y}_{\mathrm{T}}$ reduced variate of a given return period ' $\mathrm{T}$ ' given by $\mathrm{Y}_{\mathrm{T}}=-(\mathrm{LN} * \mathrm{LN}(\mathrm{T} / \mathrm{T}-1))$ or $=$ $(0.834+2.303 \log \cdot \log (\mathrm{T} / \mathrm{T}-1))$. 
here $T$ is return period, $Y n$ is reduced mean obtained from Gumbel frequency table and $\mathrm{Sn}$ is reduced standard deviation.

\section{Log-Pearson type III}

Log-Pearson type III distribution, first proposed by Foster in 1924 and revised later in 1967 by U.S. Weather Resources Council is widely used in hydrologic frequency analysis, particularly for flood peak data (Lee 2012; Rao 2017). The distribution is a three-parameter gamma function with a logarithmic transform of the variable. The log-Pearson Type III distribution differs from most other distribution methods in that the three parameters mean (Za), standard deviation (STDV), and the coefficient of skew (K) are necessary to describe the distribution.

The designed Log Pearson Type III for this study is expressed as

$\mathrm{Z}=\mathrm{Z}_{\mathrm{a}}+\mathrm{K}_{\mathrm{z}} * \mathrm{STDV}$

where $K z$ is frequency factor taken from table with coefficient of skew values 'Cs' at recurrence interval ' $\mathrm{T}$ ', $S T D V$ Standard Deviation of the ' $\mathrm{Z}$ ' variate sample and Za mean of the 'ZT' variate.

$\mathrm{Cs}=\left(\mathrm{N} \Sigma(\mathrm{Z}-\mathrm{Zavg})^{\wedge} 3\right) /(\mathrm{N}-1)(\mathrm{N}-2)\left(\mathrm{STDV}^{\wedge} 3\right)$

where Cs is co-efficient of skew of variate " $Z$ ", $N$ sample size i.e., number of years of record.

After finding Za with the equation above, the corresponding value of XT is obtained as Antilog of ZT.

Recurrence Interval can be calculated as: $(n+1) / m$

where $\mathrm{n}$ is number of samples (years), $m$ is rank of a given gauge level.

\subsection{Flood inundation area mapping}

River geometry information is an essential and important requirement in developing flood inundation areas using the HEC-GeoRAS/HEC-RAS hydraulic modeling software. HEC-RAS can model the steady and unsteady hydraulic analysis, and in the present instance, the former was modeled. Basic river geometries required in flood modeling include river cross-sections, stream centerlines, bank lines, flow lines, and other information. Necessary river geometry was extracted after the creation of Triangulated Irregular Network (TIN) from DEM. They are extracted from developed TIN of the study area for the HEC-GeoRAS model. Manning's n value for individual cross-sections was acquired after the land-use/land-cover map of the study area. After RAS geometry data preparation, HEC-GeoRAS model was used to generate a RAS GIS file (final river geometry file) used as input for HEC-RAS (Fig. 3). After checking the river cross-section and editing its geometry based on field verification, the final correction of the river geometry file in the HEC-RAS model was carried out. Then highest flows were imported from the Itang gauging station to generate water levels for different return periods.

\subsection{Flood hazard assessment}

In the present study, historical flood records along with yearlong discharge data were used for flood hazard assessment (FHA). Historically, 2007 is one of the high flooding times that hit Itang, causing severe damage. The FHA comprises six criteria, viz., elevation (C1), precipitation (C2), slope (C3), drainage density (C4), soil type (C5), land-use/land-cover (C6). The selection of these parameters is theoretically based on their relevance to flood hazards documented in the literature (Haan et al. 1994). Input data for each parameter is processed in 
the GIS environment, and the six parameters. The acquired values are processed in order to calculate the relative significance of each criterion and the corresponding weightage factor (w). Following the calculation of weights, FHA was calculated using Eq. (5).

$$
F H A=\sum_{i=1}^{n} \text { ri.wi }
$$

where $r i$ is rating of the parameter in each point, wi is weightage of each parameter, $n$ is number of the criteria.

\subsection{Analytical Hierarchy Process (AHP)}

Weightage of each parameter is defined following the Analytical Hierarchy Process (AHP) (Saaty 1990a, b). With the use of AHP, the relevant factor's relative significance was obtained after the construction of a pairwise comparison matrix (Mu and Pereyra-Rojas 2017). The rating score of relative significance was set up from 1 to 9, indicating less importance to much more importance of the factor in that order (Table 2).

\subsection{Pair-wise comparison}

In the matrix of pair-wise comparison, each of the criteria is considered a causative factor of flooding in Itang compared to the practice in other places, where only one of the two criteria is expected to have more influence. In the comparison, all the criteria did not exercise the same influence. For example, if both criteria $\mathrm{C} 1$ and $\mathrm{C} 2$ had the same influence, the pair received an index of 1 . But when compared to criterion $\mathrm{C} 2$, if criteria $\mathrm{C} 1 \mathrm{had}$ come up with more influence, then the pair received its value as any rating between 9 to 2 (Table 3). According to Saaty (1977a), criteria rating below or equal to 0.1 is an acceptable reciprocal matrix, whereas a ratio over 0.1 unacceptable compelling a reexamination of the matrix. To identify and locate inconsistent decisions with regard to their importance, pair-wise comparisons were relied.

\subsubsection{Consistency check}

Consistency of the created eigenvector matrix for AHP was evaluated. The required level of consistency was evaluated using the following index:

$$
C R=\frac{C I}{R I}
$$

where $C R$ is consistency ratio, $C I$ consistency index, and $R I$ random index.

For the values in Table 4, random consistency indices $(R I)$ are tabulated. Thus, in this study, the $R I=1.25$. The acceptable $C R$ must be $<0.1$. CI is calculated using Eq. (7) where calculated $\lambda_{\max }=6.55$.

$$
C I=\frac{\lambda \max -n}{n-1}
$$

Eventually, calculated consistency ratio 0.087 is lower than the threshold value of 0.1 , thus affirming the weightage consistency. 


\section{Results}

\subsection{Flood frequency}

Flood frequencies were obtained from Gumbel's distribution for different year return periods (YRPs) prepared based on the log chart. They recorded historical peak discharge for different years were presented in Tables 5 and 6. The discharges predicted by Gumbel's distribution for 5, 10, 25, 50 and 100 year return period flood were $1394 \mathrm{~m}^{3} / \mathrm{s}, 1535 \mathrm{~m}^{3} / \mathrm{s}, 1712 \mathrm{~m}^{3} / \mathrm{s}, 1844 \mathrm{~m}^{3} / \mathrm{s}$, and $1974 \mathrm{~m}^{3} / \mathrm{s}$, respectively while, calculated discharge of the Baro River from log-Pearson Type III distribution were $1389 \mathrm{~m}^{3} / \mathrm{s}, 1432 \mathrm{~m}^{3} / \mathrm{s}, 1461 \mathrm{~m}^{3}, 1473 \mathrm{~m}^{3} / \mathrm{s}, 1480 \mathrm{~m}^{3}$, respectively. These flood discharges were tested for their goodness of fit through Chi-square test statistic. Accordingly, log-Pearson Type III distribution showed low Chi-Square result (3.836), at a P value of 0.429, thereby revealing that it is not significant at a P-value $\leq 0.05$, whereas Gumbel's distribution showed a ChiSquare of 127.959 , at a $\mathrm{P}$ value of $<0.001$.

\subsection{Flooded inundation map}

Results of model sensitivity to changes at selected intervals were presented in Fig 4. Based on the result of HEC-RAS, elevation of water column of the areas that would be inundated within 5, 10, 25, 50, and 100 year recurrence intervals were identified. And then, the mean elevation of these areas was calculated further to combine them with each recurrence interval's water levels. The average elevation of the water columns thus arrived for various recurrence intervals was found to be $413.99 \mathrm{~m}, 414.21 \mathrm{~m}, 414.45 \mathrm{~m}, 414.82 \mathrm{~m}$, and 415.58 $\mathrm{m}$, respectively, for $5,10,25,50$, and 100 years. This information will help predict the extent of flood inundation areas. Accordingly, if floods arise at recurrence intervals of 5, 10, 25, 50, or 100 years, inundation is expected to ensue in areas with elevation lower than the computed mean water levels. Figure 5 depicts areas likely to be inundated within previously indicated recurrence intervals. Accordingly, $76.66 \mathrm{~km}^{2}, 80.78 \mathrm{~km}^{2}$, $84.15 \mathrm{~km}^{2}, 87.34 \mathrm{~km}^{2}$ and $100.34 \mathrm{~km}^{2}$ of land areas are predicted to be inundated by floods at $5,10,25,50$, and 100 years of recurrence intervals. From these inundation maps, locations found along the Baro River banks, especially the flat flood plain area to the west of the study area, are predicted to flood during all five recurrence intervals.

\subsection{Flood factors}

The occurrence of a flood depends on several topographic and climatic factors of an area. Combined assessment of all known factors using modern techniques can provide a detailed picture of the flood hazard vulnerable locations to different magnitudes.

\section{Elevation and slope}

Water flows from higher to lower elevations, and therefore slope influences the amount of surface runoff and infiltration. Flat areas in low elevations may flood quicker than areas in higher elevations with a steeper slope. Naturally, low slopes and low elevation have been assigned the highest rating as flood-prone areas. The elevation of an area can be divided into five classes. The results of reclassified elevation based on the natural break (Junk) indicate that about $776.52 \mathrm{~km}^{2}$ (35.67\%) of Itang has low elevation is very high prone to flooding, $567.96 \mathrm{~km}^{2}$ (26.09\%) highly prone, $440.48 \mathrm{~km}^{2}$ (35.67 \%) medium prone, $263.67 \mathrm{~km}^{2}(12.11 \%)$ low prone and $128.23 \mathrm{~km}^{2}(5.89 \%)$ very low prone to flooding (Fig. 6a). From among different places in the district, areas with 
lower elevations are more exposed to flood hazards. Areas found along the flood plain of the Baro River and low land areas bordering with Lare, in Gambella region in the western part of the study area are more affected by flooding.

Localities to the east of the study area (upstream of the Baro) that merge with the adjacent lands experience relatively limited flooding compared to longer continuous flat slope areas found downstream the river (Fig. 6b). The gradient of the study area can be divided into five slope classes, viz., very low $\left(>20^{\circ}\right)$, low $\left(10-20^{\circ}\right)$, moderate $\left(7-9^{\circ}\right)$, high $\left(4-6^{\circ}\right)$, and very high $\left(0-3^{\circ}\right)$ slopes, respectively.

\section{Rainfall}

Rainfall has a significant relationship with river discharge, and it directly influences the occurrence of floods. The spatial distribution of rainfall intensity is considered based on the allocation of stations in the study area. Heavy rainfall from the region and surrounding highland Oromiya regions is the main cause of the Baro river's flooding in the southwestern part of the area, with relatively lower precipitation than the northern and eastern parts. Thus annual rainfall in the study area was more than $1800 \mathrm{~mm}$ in some places, whereas it was less than $481.6 \mathrm{~mm}$ in other places. Figure 7 presents the areas with very high and high rainfall in high lands, especially the northern and northeastern parts adjoining with the surrounding Oromiya Zone. According to reclassified data, $304.11 \mathrm{~km}^{2}$ or $13.97 \%$ of Itang received high rainfall, followed by $885.66 \mathrm{~km}^{2}$ or $40.7 \%$ medium rainfall and $814.24 \mathrm{~km}^{2}$ or $37.41 \%$ low rainfall. The areas receiving very low and very high rainfall in Itang accounted for $49.72 \mathrm{~km}^{2}$ or $2.28 \%$ and $122.59 \mathrm{~km}^{2}$ or $5.63 \%$, respectively (Table 7 ).

\section{Drainage}

The reclassified drainage density map of Itang shows that $253.35 \mathrm{~km} 2(11.64 \%)$ is of very high, $551.41 \mathrm{~km}^{2}$ (25.34\%) high, $681.32 \mathrm{~km}^{2}(31.31 \%)$ with medium $513.49 \mathrm{~km}^{2}(23.6 \%)$ low, and $176.36 \mathrm{~km}^{2}(8.1 \%)$ very low density (Fig. 8a, b). As per the adopted reclassification, areas around big rivers like the Baro River have very high drainage density. Drainage density of the study area was calculated to be $2.5 \mathrm{~km} / \mathrm{km}^{2}$.

\section{Land-use/land-cover}

Land-use/land-cover influences the infiltration rate, depending upon the interrelationship between surface water groundwater and debris flow. While forests and lush vegetation favor rainwater infiltration, urban land supports surface overflow. Land-use/land-cover of the study area reveals eight major types of land-use/land-cover: cropland, woodland, grassland, wetland, forest, shrubland, settlement, and water body (Fig. 9). Vegetation cover in Itang has reduced mainly due to increased large and small-scale agricultural activities and this promotes runoff due to increase in paved surfaces. The moisture content of the land also affects the flooding condition. Lands with low moisture content have the capability of absorbing more water compared to areas with higher moisture content. Wetlands along the Baro and adjacent areas of Lare are highly affected by flooding. Of the total study area, $1069.9 \mathrm{~km}^{2}(49.2 \%)$ of land is covered by cropland, followed by woodland $798 \mathrm{~km}^{2}(36.7 \%)$ of area. Wetland, grassland/bare soil, forest and water body share $83.9 \mathrm{~km}^{2}(3.9 \%), 60.7 \mathrm{~km}^{2}(2.8 \%), 36 \mathrm{~km}^{2}$ $(1.7 \%)$, and $14.7 \mathrm{~km}^{2}(0.7 \%)$, respectively. The remaining area covers settlement and shrubland with $12.1 \mathrm{~km}^{2}$ $(0.6 \%), 7 \mathrm{~km}^{2}(0.46 \%)$ of area, respectively. Accuracy assessment result for land-use/land-cover for 2017 shows an overall precision was $90.6 \%$ with Kappa equal to 0.86 . 


\section{Soil}

The nature of the soil in a given area can influence the flood condition and possibly determine the infiltration capacity. According to the soil classification of MoWIEE, most of the different soil types $\left(1149.5 \mathrm{~km}^{2}\right)$ in Itang are highly vulnerable to floods because of their nature, i.e., Dystric and Eutric Fluvisols that occupy $53.2 \%$ of the area (Fig. 10). The Dystric and Chromic Cambisols, located in a very high flood zone, cover $514.2 \mathrm{~km}^{2}$ or about 23.8\%, whereas Dystric and eutric Plinthosols, classified as soil type of medium flood hazard zone; cover an area of $252.5 \mathrm{~km}^{2}(11.7 \%)$. About $195.4 \mathrm{~km}^{2}(9.1 \%)$ and $47.6 \mathrm{~km}^{2}(2.2 \%)$ of the land are coved with Planosol and Eutric Gleysol soils of low and very low flood-prone types.

\subsection{Flood hazard assessment}

Table 9 describes the flood hazard zones levels and the corresponding degrees of flood risk susceptibility. Out of a total area of $2145.4 \mathrm{~km}^{2}, 12.7 \%$ falls in the category of 'very high' flood susceptibility risk, followed by $27.8 \%$ high risk, $29.7 \%$ medium risk, $18.5 \%$ low risk, and $11.3 \%$ low risk categories. Validation of the output maps was tested by overlaying selected flood-prone area field verification (Fig. 11). Local people were interviewed to decipher previous flood conditions and the damages they caused. Areas within the flood plain were affected by the land-use/land-cover characteristics. In order to understand the status of flood hazard in various Kebeles of the Itang District, the flood hazard map was corroborated with the Kebeles. Accordingly, out of 21 Kebeles in the area, six (Itang Town, Birhan Selam, Puldang, Ajuw, Akura and Awngi) are situated in the very high flood zone, and ten Kebeles (Watigachi, Pilwal, Beljakok, Dorong, Aleha, Adima, Etange Ker, Achuwa, Pukumu, and Ebago) high flood zone. War, Badel, Adong, and Aliya are rural Kebeles that fall medium flood zone, whereas Wanke, the less affected Kebele is located in low hazard zone. These observations coincide with the Itang District officials' information except for their classification as high and medium flood vulnerable Kebeles.

Further, the results of land-use/land-cover classes and their spatial distribution in flood hazard zone are validated to find out flood vulnerable in the region. Cropland: Majority $\left(351.53 \mathrm{~km}^{2}\right)$ of the total cropland extending to is located in high flood hazard zone, followed by $321 \mathrm{~km}^{2}(30.27 \%)$ in medium hazard zone and $168 \mathrm{~km}^{2}(15.84 \%)$ low hazard, $155.8 \mathrm{~km}^{2}$ in low and $64.12 \mathrm{~km}^{2}$ very low hazard zones. Grassland: Of the total area covered by grassland/bare soil, $21.82 \mathrm{~km}^{2}(36.18 \%)$ in found in medium hazard zone, $15.99(26.52 \%)$ in high, 14.7 (24.38\%) in low, $3.91(6.48 \%)$ in very low and $3.88 \mathrm{~km}^{2}(6.44 \%)$ in very high hazard zones. Forest: Of the land covered by forest, $9.19 \mathrm{~km}^{2}(25.95 \%)$ in located in medium flood hazard zone, whereas $8.82 \mathrm{~km}^{2}$ (24.95\%) in high, $7.96 \mathrm{~km}^{2}(22.48 \%)$ in very low, $5.5 \mathrm{~km}^{2}(15.53 \%)$ in low and $3.94 \mathrm{~km}^{2}(11.14 \%)$ in very high hazard zones, respectively. Settlement: Of the settlement areas $5.92 \mathrm{~km}^{2}(49.17 \%)$ is located in high, $3.5 \mathrm{~km}^{2}$ (29.05\%) in medium, $2.34 \mathrm{~km}^{2}(19.44 \%)$ in very high, $0.25 \mathrm{~km}^{2}(2.06 \%)$ in low and $0.03 \mathrm{~km}^{2}(0.28 \%)$ in very low hazard zones. Shrub land: Majority $\left(30.88 \mathrm{~km}^{2}\right.$ or $\left.31.67 \%\right)$ of the total land covered by shrub and bush class is located in very low hazard zone, whereas $26.42 \mathrm{~km}^{2}(27.1 \%), 23.35 \mathrm{~km}^{2}(23.94 \%), 15.67 \mathrm{~km}^{2}(16.07 \%)$ and $1.19 \mathrm{~km}^{2}(1.22 \%)$ are found in medium, low, high and very high hazard zones, respectively. Waterbody: An extent of $6.88 \mathrm{~km}^{2}(47.82 \%)$ of land area covered by water bodies is located in high flood hazard zone and 2.31 $\mathrm{km}^{2}(16.06 \%)$ in medium hazard zone. Areas found in very high, low, and very low hazard zones are $2.31 \mathrm{~km}^{2}$ (16.06\%), $1.46 \mathrm{~km}^{2}(10.15 \%)$, and $0.15 \mathrm{~km}^{2}(1.04 \%)$, respectively. 
Wetland: The land-use/land-cover class 'wetland' found along river banks and to the western corner of the study area highly prone to flood in Itang. Of the total wetlands, $44.69 \mathrm{~km}^{2}(54.03 \%)$ is located in the very high flood hazard zone followed by $28.22 \mathrm{~km}^{2}(34.12 \%)$ high hazard, $2.6 \mathrm{~km}^{2}(3.15 \%)$ medium hazard, $2.6 \mathrm{~km}^{2}(3.15 \%)$ in low and $1.01 \mathrm{~km}^{2}(1.23 \%)$ in very low hazard zones. Woodland: Of the second dominant land-cover class, the woodland in the study area; $244.92 \mathrm{~km}^{2}(31.3 \%)$ lies in medium, $180.67 \mathrm{~km}^{2}(23.09 \%)$ in low, $162.96 \mathrm{~km}^{2}$ (2082\%) in high, $136.39 \mathrm{~km}^{2}(17.43 \%)$ in very low and $57.6 \mathrm{~km}^{2}(7.36 \%)$ in very high flood hazard zones.

\subsection{Model validation}

Many models are used by researchers to analyze flood susceptibility in various regions of the world, but it is essential to validate the results of the model in order to that the model is representing a true ground situation or the recorded observations sufficiently. Model calibration and validation can be done by comparing model output with observed data. For the study area there are no available observed stream flows. Therefore, the results of the success rate were obtained using a training dataset, while its prediction accuracy was calculated using the validation dataset not employed in the training process.

\section{Discussion}

The methodology proposed for the estimation of flood hazard areas is a useful tool for the mitigation of the devastating impact of floods. Flood hazard is damage to the development and people from flooding. The effects of floodwaters are dangerous to personal safety, infrastructure, and agricultural lands in the area (Daffi et al. 2014; Asare-Kyei et al. 2015; Das 2019). Studies on flood hazard assessment will contribute basic and essential information on floods to the people, flood maps preparation by civil protection in advance and help or safety planning purposes has also become widely understood (Pagliara 2006; Tien Bui et al. 2019). Itang is one of the flood prone locations in Ethiopia and hence flood hazard assessment and mapping was carried out through remote sensing and GIS. Flood triggering factors such as slope, elevation, rainfall data, discharge data, soil type data, and land-use/land-cover data were evaluated giving weightage to adopted techniques of AHP. Consistency of the weightages given for each of the criteria used was also checked by means of consistency ratio before applying MCE technique employed for the preparation of final flood hazard map. Accordingly, hydrological simulations under different flood scenarios can be a valuable tool, especially in areas where such data are available. An additional contribution of flood simulation models is a direct estimation of the role of the various criteria in a flood event (Zou et al. 2013; Huang et al. 2014). A further step is the estimation of the peak discharge and exceedance probability at locations where flood hazard is high/very high. Thus, advanced information related to flood hazard areas will easily reach the local people through flood hazard maps (Haq et al. 2012; Bui et al. 2019). And this will aid the people in summoning awareness about the vulnerable areas surrounding their habitats and croplands.

Through flood hazard studies, lower areas around the rivers can be categorized into a series of hazard zones based on the level and extent of flooding (Pradhan 2010; Khosravi et al. 2018). Due to this study, the Itang district, subjected to different flood levels, was classified into very high, high, medium, low, and very low hazard zones. From the flood hazard map prepared, almost all the areas along the Baro river, mainly those downstream, were more exposed to flooding. The terrain of these areas are generally flat compared to other parts of the district. Twenty of the twenty-one Kebeles found in Itang are all situated within this Baro flood 
plain. During the field data collection, especially in areas close to Itang town and accessible surrounding rural Kebeles, various activities of the people were observed. The population lives along the river carrying out different economic activities. Agricultural and fishing are practiced more in these areas, these activities are severely affected in the event of flooding. Further, disruption in transportation and commutation in the area due to flooding, different commercial practices also get utterly disrupted for a prolonged period, resulting in several difficulties, including communication and food availability.

In general, flooding has a long history in Itang and Gambella region (Woube 1999; Haile et al. 2013). Historical records indicate that flooding has increased over the years, becoming a common annual phenomenon in the region. High rainfall from June-September and at times to October is the major factor causing floods. According to information from Disaster Preparedness and Prevention (DPP) office of the Gambella, an estimated 40,000 people have been affected by floods in the eleven chronically flood-prone districts, viz., Gog, Jor, Lare, Itang, Wanthoa, Akobo, Jikaw, Makuey, Dimma, Abobo, and Gambella of the region besides Gambella town in the year 2017. However, evidences obtained from the local people and different reports indicate that there are not enough disaster preparedness and prevention strategies in the district. On the other hand, structural measures were also not taken even by the regional government due to poor economy of the country in general (Abaya et al. 2009; Wondim 2016). Relocation strategy is considered as a common solution to the flooding problem. Information obtained from the local people discloses that people are accommodated in schools, and churches, while others migrate to the highway/road at the time of flooding. Therefore, every need for the adoption of additional strategies should be applied to cope with the flooding situation of the area to keep the crops safe and the people comfortable during difficult times based on the facts and figures generated during this study.

Warm weather conditions of the Gambella region constrain people of the area to settle close to rivers for want water. However, these locals' settlement is not planned but happens devoid of any cognizance of the imminent hazard. Therefore, sufficient knowledge should be generated including land-use plan of the area so as to mitigate or thwart flood problems in the area. Adjei-darko (2017) suggested preparation of integrated drainage master plan considering the existing built-up spaces, expanses currently under development and future development zones will benefit in such (flood hazard) occasions. With regard to preparedness, anticipated flood events need to be appropriately estimated based on satellite imageries, updated rainfall intensity and its duration. Therefore, an integrated design for the land resources management, especially for flood hazard areas is desirable. An integrated design is important for decision-making as, creates a roadmap for the required flood mitigation measures. However, it is beyond the scope of the present study to conduct a study with in-depth methodological changes on different parameters, assuming the pros and cons of this model (Bui et al. 2016; Seejata et al. 2018; Bui et al. 2019). Parameters can be added or removed according to local hydrogeological, hydrological, and morphological characteristics.

\section{Conclusion}

Flooding is a serious, catastrophic event that can occur practically anywhere along river courses, especially downstream. Controlling flood effects through appropriate management is a crucial consideration worldwide. The main aim of the present study is to delineate flood prone areas of Itang and identify more vulnerable areas through integration of remote sensing and GIS techniques. Multi-criteria method was applied in combining the 
decision measures i.e., elevation, slope, rainfall, drainage density, land-use and land-cover and soil type used in this study. Based on the methodologies adopted for the study, majority of the area along the Baro river is found to experience high level of flooding. The whole of Itang district experienced flood hazard of different magnitudes right from very high to very low level. About $271.8 \mathrm{~km}^{2}(12.7 \%)$ of the total land area was noted to be lying in the very high flood hazard zone. Overall, the classification results were favorable though certain deficiencies in its application. The information and the knowledge gained from the outcomes of the present study would assist local authorities and government agencies accurately identifying the flood susceptible areas and help in implementing appropriate flood management plans in such localities.

\section{Acknowledgements}

We are thankful to the head and staff of the School of Earth Sciences, College of Natural and Computational Sciences, Addis Ababa University, for providing all kinds of necessary facilities and support during the present study. We are also thankful to Ministry of Water, Irrigation and Electricity of Ethiopia and Gambella Disaster Preparedness and Prevention Office for providing all the necessary data required for the present study. We also thankfully acknowledge data support from National Metrological Service Agency.

\section{Authors Contributions}

The first author Mr. Dame Tadesse carried out the research and collected data, analyzed and prepared maps, Dr. Surya supervised the research and approved the findings and wrote the final manuscript, Dr. Dessie Nedaw thoroughly reviewed technical contents, provided required inputs. All the authors reviewed and approved the final manuscript version.

\section{Founding}

The authors received no direct funding for this research

\section{Availability of data and materials}

All materials used for the article compilation are properly cited

\section{Competing interests}

The authors have no competing interest.

\section{References}

Abaya SW, Mandere N, Ewald G (2009) Floods and Health in Gambella region, Ethiopia: An Assessment of the strength and weakness of the coping mechanisms. Good Health Action. doi:10.3402/gha.v2i0

Abebe Feyisa (2007) Flood Hazard Assessment Using GIS in Becho Plain, Upper Awash Valley, South West of Addis Ababa. Addis Ababa. Unpublished MSc Thesis, Addis Ababa University, Addis Ababa, Ethiopia

Adjei-Darko P (2017) Remote Sensing and Geographic Information Systems for Flood Risk Mapping and Near Real-time Flooding Extent Assessment in the Greater Accra Metropolitan Area

Amare GN, Okubay GA (2019) Flood hazard risk vulnerability mapping using Geo-spatial and MCDA around Adigrat, Tigray Region, Northern Ethiopia. Momona Ethiopian Journal of Science, 7(1):90-107

Alemu YT (2015) Flash Flood Hazard in Dire Dawa, Ethiopia. J. Social Sci. Humanities 1 (4):400-414 
Asare-Kyei D, Forkuor G, Venus V (2015) Modeling flood hazard zones at the sub-district level with the rational model integrated with GIS and remote sensing approaches. Water 7:3531-3564

Ashley WS, Strader S, Rosencrants T, Krmenec AJ (2014) Spatiotemporal changes in tornado hazard exposure: the case of the expanding bull's-eye effect in Chicago, Illinois. Weather Clim Soc 6:175-193

Azouagh A, El Bardai R, Hilal I, Stitou el Messari J (2018) Integration of GIS and HEC-RAS in Floods Modeling of Martil River (Northern Morocco). Eur. Sci. J. 14, 130

Ballesteros-Cánovas JA, Sanchez-Silva M, Bodoque JM., et al., (2013) An integrated approach to flood risk management: a case study of Navaluenga (Central Spain). Water Resour. Manage. 27 (8), 3051-3069

Barua U, Akhter MS, Ansary MA (2016) District-wise multi-hazard zoning of Bangladesh. Nat Hazards 82:1895-1918

Bronstert A (2003) Floods and climate change: Interactions and impacts. Risk Analysis, 23(3):545-557

Bryan E, Deressa TT, Gbetibouo GA, Ringler C (2009) Adaptation to climate change in Ethiopia and South Africa: options and constraints. Environmental Science and Policy, 12:413-426.

Brunner GW (2016) HEC-RAS, River Analysis System Hydraulic Reference Manual; US Army Corps of Engineers Hydrologic Engineering Center: Davis, CA, USA, 2016; pp. 1-547

Bui DT, Pradhan B, Nampak H, Bui QT, Tran QA, Nguyen QP (2016) Hybrid artificial intelligence approach based on neural fuzzy inference model and metaheuristic optimization for flash flood susceptibility modeling in a high-frequency tropical cyclone area using GIS. J. Hydrol. 540:317-330

Bui DT, Tsangaratos P, Ngo PTT, Pham TD, Pham BT (2019) Flash flood susceptibility modeling using an optimized fuzzy rule based feature selection technique and tree based ensemble methods. Sci. Total Environ. 668:1038-1054

Chapi K, Singh PV, Shirzadi A, Shahabi H, Tien Bui D, Pham TB, Khosravi K (2017) A novel hybrid artificial intelligence approach for flood susceptibility assessment. Environ.Model. Softw. 95:229-245

Daffi RE, Otun JA, Isamail (2014) Flood hazard assessment of River Dep floodplains in North-Central Nigeria. Int. J. Water Resour. Environ. Engr. 6(2):67-72

Danumah JH, Odai SN, Saley B.M., et al. (2016) Flood risk assessment and mapping in Abidjan district using multi-criteria analysis (AHP) model and geoinformation techniques,(cote d'ivoire). Geoenviron Disasters 3:10

Das S (2019) Geospatial mapping of flood susceptibility and hydro-geomorphic response to the floods in Ulhas Basin, India. Remote Sens. Appl. Soc. Environ.14, 60-74

de Brito MM, Evers M (2016) Multi-criteria decision-making for flood risk management: a survey of the current state of the art. Nat Hazards Earth Syst Sci 16:1019-1033

Deng WP, Zhou JZ (2013) Approach for feature weighted support vector machine and its application in flood disaster evaluation. Disaster Adv. 6 (4):51-58

Devi GK, Ganasri BP, Dwarakish GS (2015) A review on hydrological models. Aquatic Procedia 4, 1001-1007

Dewan AM, Islam MM, Kumamoto T, Nishigaki M (2007) Evaluating flood hazard for land-use planning in Greater Dhaka of Bangladesh using remote sensing and GIS techniques. Water Resour Manag 21:1601.

Elsafi SH (2014) Artificial neural networks (ANNs) for flood forecasting at Dongola station in the River Nile Sudan, Alexandria Engineering Journals, 53(3):655-662

Feloni E, Mousadis I, Baltas E (2020) Flood vulnerability assessment using a GIS-based multi-criteria approach- The case of Attica region. J. Flood Risk Management, 13(Suppl. 1):e12563 
Fernández D, Lutz M (2010) Urban flood hazard zoning in Tucumán Province, Argentina, using GIS and multicriteria decision analysis. Eng Geol. 111:90-98

Getahun YS, Gebre SL (2015) Flood hazard assessment and mapping of flood inundation area of the Awash River Basin in Ethiopia using GIS and HEC-GEORAS/HEC-RAS Model. J. of Civil and Environmental Engineering, 5(4):1-12

Gigovi'c L, Pamu`car D, Baji'c Z, Drobnjak S (2017) Application of GIS-Interval rough AHP methodology for flood hazard mapping in urban areas. Water 9 (360):1-26

Guthrie RH, Cuervo V (2015) Geohazards and Risk: A Proponent's Guide to Linear Infrastructure. Yukon Environmental and Socio-economic Assessment Board, Whitehorse, YT, 47 pp + Appendices

Haile AT, Kusters K, Wagesho N (2013) Loss and damage from flooding in the Gambela region, Ethiopia.Int. J. Global Warming. 5(4):483-497

IPCC (2007) Climate Change. Impacts, adaptation and vulnerability. Contribution of Working Group II to the Fourth Assessment Report of the Intergovernmental Panel on Climate Change. Cambridge, United Kingdom and New York, NY, USA: Intergovernmental Panel on Climate Change

IPCC (2012) Managing the Risks of Extreme Events and Disasters to Advance Climate Change Adaptation: Special Report of the Intergovernmental Panel on Climate Change, Cambridge University Press 32 Avenue of the Americas, New York, NY 10013-2473, USA

Haan C, Barfield B, Hayes J (1994) Design hydrology and sedimentology for small catchments. Elsevier

Haile AT, Kusters K, Wagesho N (2013) Loss and damage from flooding in the Gambela Region, Ethiopia, International journal of Global Warming. 5:483-497

Haq M, Akhtar M, Muhammad S, Paras S, Rahmatullah J (2012) Techniques of remote sensing and GIS for flood monitoring and damage assessment: a case study of Sindh province, Pakistan. Egypt. J. Rem. Sens. Space Sci. $15: 135-141$

Hong H, Tsangaratos P, Ilia I, Liu J, Zhu A.-X, Chen W (2018a) Application of fuzzy weight of evidence and datamining techniques in construction of flood susceptibility map of Poyang County. China. Sci. Total Environ. 625:575-588

Huang C, Chen Y, Wu J (2014) Mapping spatio-temporal flood inundation dynamics at large riverbasin scale using time-series flow data and MODIS imagery. Int. J. Appl. Earth Observ. Geoinf. 26:350-362

Islam M, Sado K (2000a) Flood hazard assessment in Bangladesh using NOAA AVHRR data with geographical information system. Hydrol Process. 14:605-620

Jonathan DW, Jennifer LI, Suzana JC (2013) Coastal flooding by tropical cyclones and sea-level rise. Nature $504,44-52$

Khosravi K, Pourghasemi HR, Chapi K, Bahri M (2016) Flash flood susceptibility analysis and its mapping using different bivariate models in Iran: a comparison between Shannon's entropy, statistical index, and weighting factor models. Environ Monit Assess. 188

Khosravi K, Pham BT, Chapi K, Shirzadi A, Shahabi H, Revhaug I, Prakash I, Bui DT (2018) A comparative assessment of decision trees algorithms for flash flood susceptibility modeling at Haraz Watershed, Northern Iran. Sci. Total Environ. 627:744-755

Kia MB, Pirasteh S, Pradhan B, Mahmud AR, Sulaiman WNA, Moradi A (2012) An artificial neural network model for flood simulation using GIS: Johor River Basin, Malaysia. Environ Earth Sci. 67:251-264

Kowalzig J (2008) Climate, poverty, and justice: What the Poznań UN climate conference needs to deliver for a fair and effective global deal. Oxfam Policy and Practice: Climate Change and Resilience 4. 3, pp. 117-148 
Lee MJ, Kang JE, Jeon S (2012) Application of frequency ratio model and validation for predictive flooded area susceptibility mapping using GIS. IEEE Int. Geosci. Remote Sens. Symp. (IGARSS). IEEE, pp. 895-898

Luu C, Von Meding J, Kanjanabootra S (2018) Assessing flood hazard using flood marks and analytic hierarchy process approach: a case study for the 2013 flood event in Quang Nam, Vietnam. Nat Hazards 90:1031-1050

Mina F, Ying TP (2015) GIS Techniques for Flood Modeling and Flood Inundation Mapping. Department of Civil \& Structural Engineering, University Kebangsaan Malaysia, Malaysia

Mezgebedingil AG, Suryabhagavan KV (2018) Developing Flood Hazard Forecasting and Early Warning System In Dire Dawa, Ethiopia. Int. J. Adv. Multidiscip. Res. 5:11-27

Merz B, Kreibich H, Thieken A, Schmidtke, R (2004) Estimation uncertainty of direct monetary flood damage to buildings. Nat. Hazard. Earth Sys. 4:153-163

Merz B, Aerts J, Arnbjerg-Nielsen K, Baldi M, Becker A, Bichet A (2014) Floods and climate: Emerging perspectives for flood risk assessment and management. Nat Hazards Earth Syst Sci. 14: 1921-1942

Morea H. Samanta S (2020) Multi-criteria decision approach to identify flood vulnerability zones using geospatial technology in the Kemp-Welch Catchment, Central Province, Papua New Guinea. Appl Geomat. doi.org/10.1007/s12518-020-00315-6

Mu E, Pereyra-Rojas M (2017) Understanding the Analytic Hierarchy Process. Practical Decision Making, Springer Briefs in Operations Research. Springer, Cham

Ogato GS, Bantider A, Abebe K, Davide Geneletti D (2020) Geographic information system (GIS)-Based multicriteria analysis of flooding hazard and risk in Ambo Town and its watershed, West shoa zone, oromia regional State, Ethiopia. Journal of Hydrology: Regional Studies 27:100659

Opolot E (2013) Application of remote sensing and geographical information systems in flood management: a review. Res. J. Appl. Sci. Eng. Technol. 6:1884-1894

Pagliara S (2006) Flood risk mapping and mitigation in central Italy. Dip.to di Ingegneria Civile - University of Pisa, Italy

Pradhan B (2010) Flood susceptible mapping and risk area delineation using logistic regression, GIS and remote sensing. J. Spatial Hydrol. 9:1-18

Rahmati O, Zeinivand H, Besharat M (2016c) Flood hazard zoning in Yasooj region, Iran, using GIS and multicriteria decision analysis. Geomat Nat Hazards Risk. 7:1000-1017

Rao D (2017) Hydrological and hydrodynamic modeling for flood damage mitigation in Brahmaniâ Baitarani River Basin, India. Geocarto Int 32:1004-1016

Rimba AB, Setiawati MD, Sambah AB, Miura F (2017) Physical Flood Vulnerability Mapping Applying Geospatial Techniques in Okazaki City, Aichi Prefecture, Japan. Urban Sci 1 (7):1-22

Rozalis S, Morin E, Yair Y, Price C (2010) Flash flood prediction using an uncalibrated hydrological model and radar rainfall data in a Mediterranean watershed under changing hydrological conditions. J. Hydrol. 394:245255

Saaty TL (1990a) How to make a decision: the analytic hierarchy process (ISSN 03772217)

Saaty TL (1990b) An exposition of the ahp in reply to the paper remarks on the analytic hierarchy process. Manag. Sci. 36 (3):259-268

Samela CR, Sole A, Manferda S (2018) A GIS tool for Cost-effective delineation of flood-prone areas. Comput.Environ.Urban Syst. 70:43-52 
Santillan JR, Marqueso JT, Makinano-Santillan M, Serviano JL (2016) Beyond Flood Hazard Maps: Detailed Flood Characterization With Remote Sensing, GIS and 2D Modeling. In: Geomatic and Geospatial Technology (GGT). 3-5 October 2016, Kuala Lumpur, Malaysia

Seejata K, Yodyinga A, Wongthadam T, Mahavika N, Tantanee S (2018) Assessment of flood hazard areas using analytical hierarchy process over the Lower Yom Basin, Sukhothai Province. Procedia Eng. 212:340-347

Shafapour Tehrany M, Shabani F, Neamah Jebur M, Hong H, Chen W, Xie X (2017) GIS-based spatial prediction of flood prone areas using standalone frequency ratio, logistic regression, weight of evidence and their ensemble techniques. Geomat Nat Hazards Risk 8:1538-1561

Shrestha S, Lohpaisankrit W (2017) Flood hazard assessment under climate change scenarios in the Yang River Basin, Thailand. International Journal of Sustainable Built Environment. 6:285-298

Smith K, Ward R (1998) Floods: Physical Processes and Human Impacts. Wiley, Chichester, p. 394

Stijn T, Patrick M, Tjeerd JB, Peter MJH, Ysebaert Tom, Vriend, Huib JDe (2013) Ecosystem-based coastal defence in the face of global change. Nature 504:79-83

Subramanya K (2008) Engineering Hydrology. Tata McGraw-Hill, 7 West Patel Nagar New Delhi

Tadesse, L., Suryabhagavan, K.V., Sridha,r G., Gizachew, L., 2017. Land use and land cover changes and soil erosion in Yezat watershed, north western Ethiopia. International Soil and Water Conservation Research 5:8594

Tehrany MS, Lee MJ, Pradhan B, Jebur MN, Lee S (2014a) Flood susceptibility mapping using integrated bivariate and multivariate statistical models. Environ. Earth Sci. 72 (10):4001-4015

Tehrany MS, Pradhan B, Jebur MN (2013) Spatial prediction of flood susceptible areas using rule based decision tree (DT) and a novel ensemble bivariate and multivariate statistical models in GIS. J. Hydrol. 504:6979

Tehrany MS, Pradhan B, Jebur MN (2014b) Flood susceptibility mapping using a novel ensemble weights-ofevidence and support vector machine models in GIS. J Hydrol 512:332-343

Tehrany MS, Shabani F, Jebur MN, Hong H, ChenW, Xie X (2017) GIS-based spatial prediction of flood prone areas using standalone frequency ratio, logistic regression, weight of evidence and their ensemble techniques. Geom. Nat. Haz.Risk 8 (2):1538-1561

Tien Bui D, Khosravi K, Shahabi H, Daggupati P, Adamowski JF, Melesse AM, Pham BT, Pourghasemi HR, Mahmoudi M, Bahrami S., et al. (2019) Flood spatial modeling in northern Iran using remote sensing and gis: A comparison between evidential belief functions and its ensemble with a multivariate logistic regression model. Remote Sens.11:1589

Trenberth KE 92011a) Changes in precipitation with climate change. Cilm Res 47:123-138

UN International Strategy for Disaster Reduction (UNISDR) (2009) Reducing Disaster Risks through Science: Issues and Actions. Geneva

U.S.Army Crops of Engineers (2002) HEC-RAC River analysis system. Hydraulic Reference Manual. Version 3.1. U.S.Army Crops of Engineers Hydrologic Engineering Centre, Davis, CA

Wang Y, Hong H, ChenW, Li S, Pamu`car D, Gigovi'c L, Drobnjak S, Bui DT, Duan HA (2019) Hybrid GIS Multi-Criteria Decision-Making Method for Flood Susceptibility Mapping at Shangyou, China. Remote Sens.11, 62

Wondim YK (2016) Flood Hazard and Risk Assessment Using GIS and Remote Sensing in Lower Awash Subbasin. Ethiopia. Journal of Environment and Earth Science 6 (9):69-86 
World Bank (2010) Report on the status of Disaster Risk Reduction in Sub-Saharan Africa. 1818 H Street, N.W. Washington, D.C. 20433, U.S.A

Winsemius HC, Van Beek LPH, Jongman B, Ward PJ, Bouwman A (2013) A framework for global river flood risk assessments. Hydrol. Earth Syst. Sci. 17, 1871-1892

Woube M (1999) Flooding and sustainable land-water management in the Baro-Akobo river basin, Ethiopia, Applied Geography, 19, 235-251

Yang TH, Ho JY, Hwang GD, Lin GF (2014) An indirect approach for discharge estimation: a combination among micro-genetic algorithm, hydraulic model, and in situ measurement. Flow Meas Instrum 39:46-53

Zou Q, Zhou J, Zhou C, Song L, Guo J (2013) Comprehensive flood risk assessment based on set pair analysisvariable fuzzy sets model and fuzzy AHP. Stoch. Environ. Res. Risk Assess. 27:525-546 


\section{Figure Legends 1-11}

Fig. 1 Location map of the study area

Fig. 2 Flow chart of the methodology

Fig. 3 The Baro river geometry map

Fig. 4 Water surface of different recurrence intervals obtained through HEC-RAS

Fig. 5 Flood inundation area of different recurrence intervals

Fig. 6 Reclassified maps (a) elevation and (b) slope

Fig. 7 Reclassified rainfall map

Fig. 8 Drainage map (a), and reclassified drainage density map (b)

Fig. 9 Land-use/land-cover map (a), and reclassified land-use/land-cover map (b)

Fig. 10 Reclassified soil map

Fig. 11 Flood hazard map 


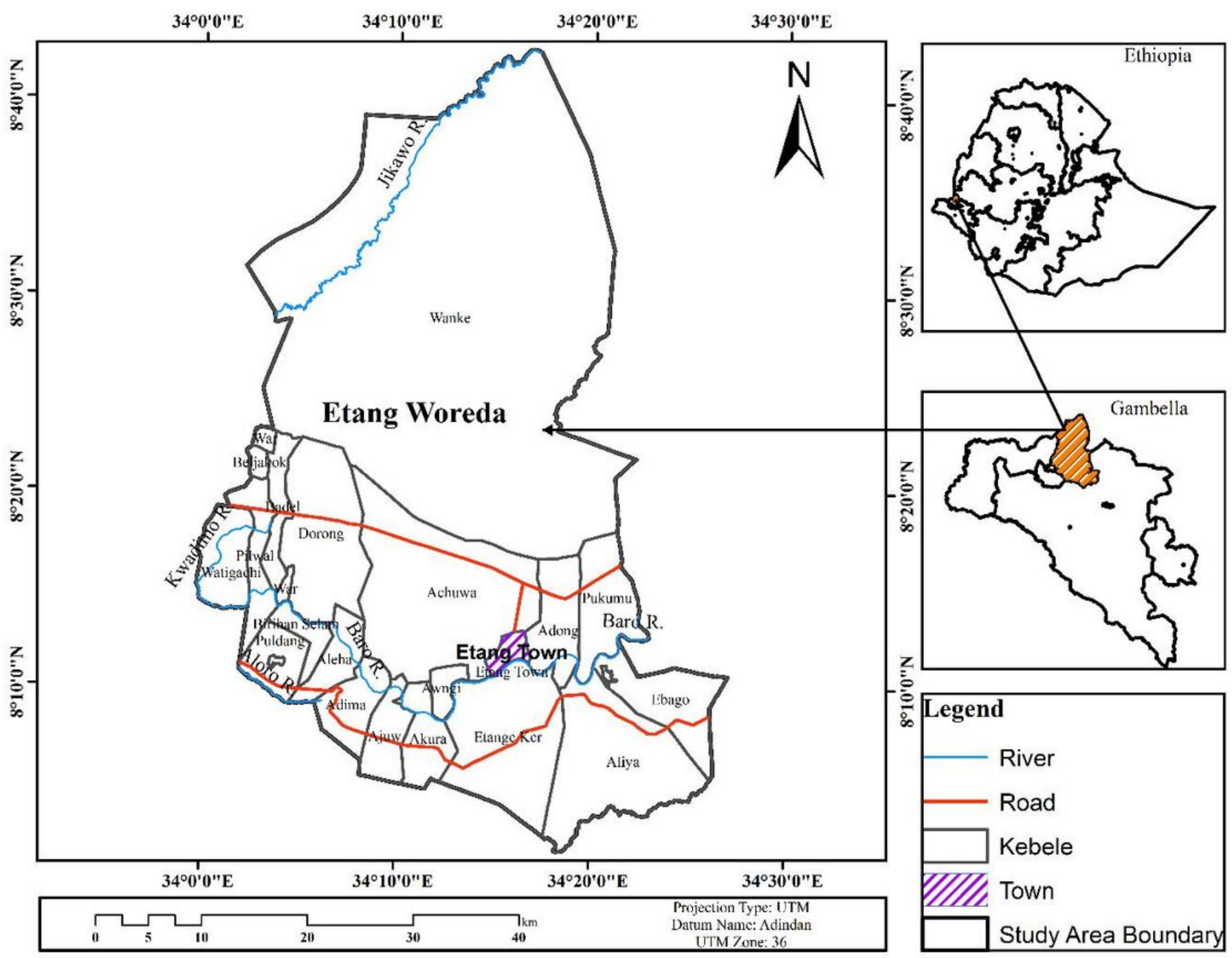

Figure 1

Location map of the study area Note: The designations employed and the presentation of the material on this map do not imply the expression of any opinion whatsoever on the part of Research Square concerning the legal status of any country, territory, city or area or of its authorities, or concerning the delimitation of its frontiers or boundaries. This map has been provided by the authors. 


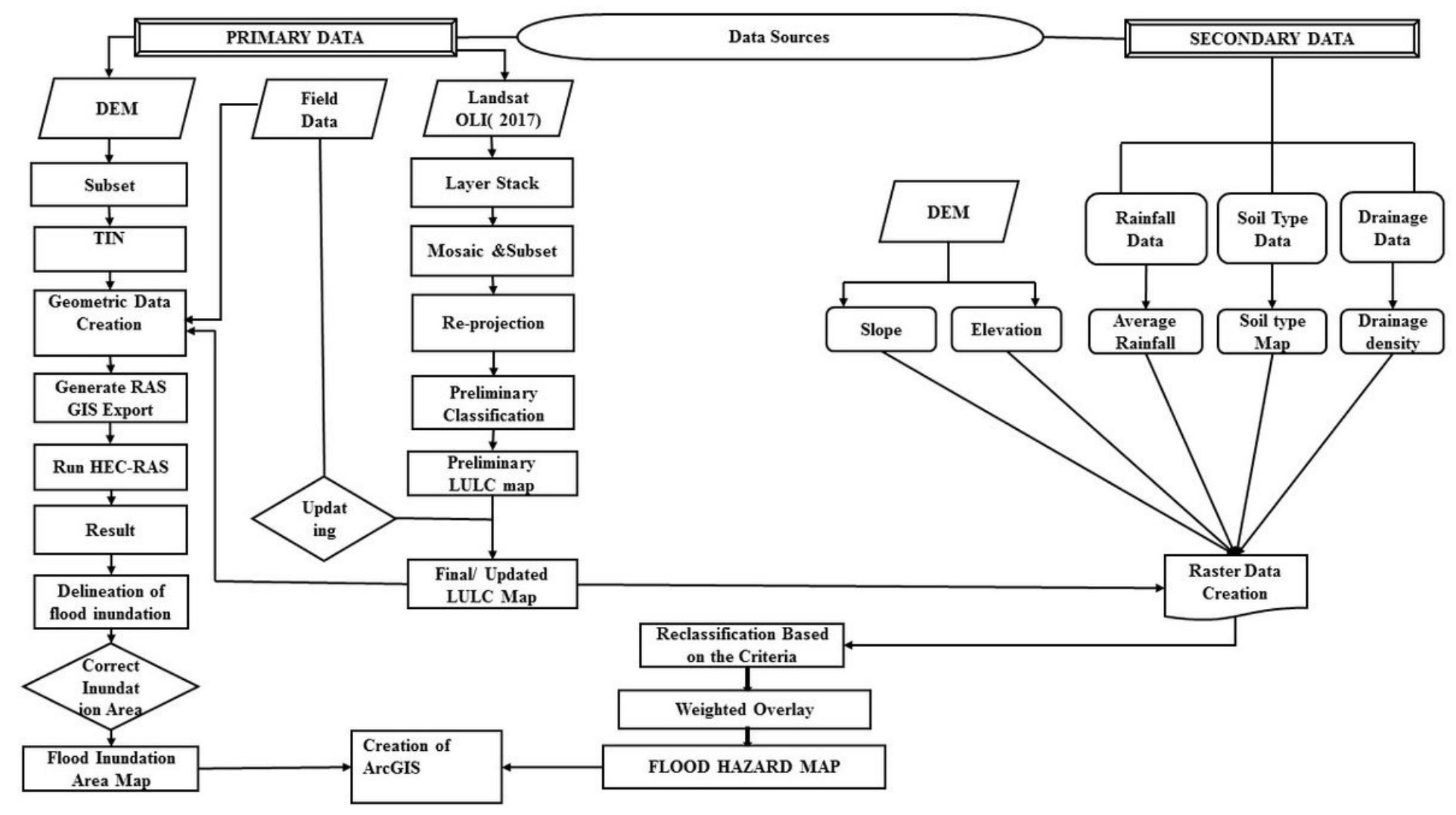

Figure 2

Flow chart of the methodology

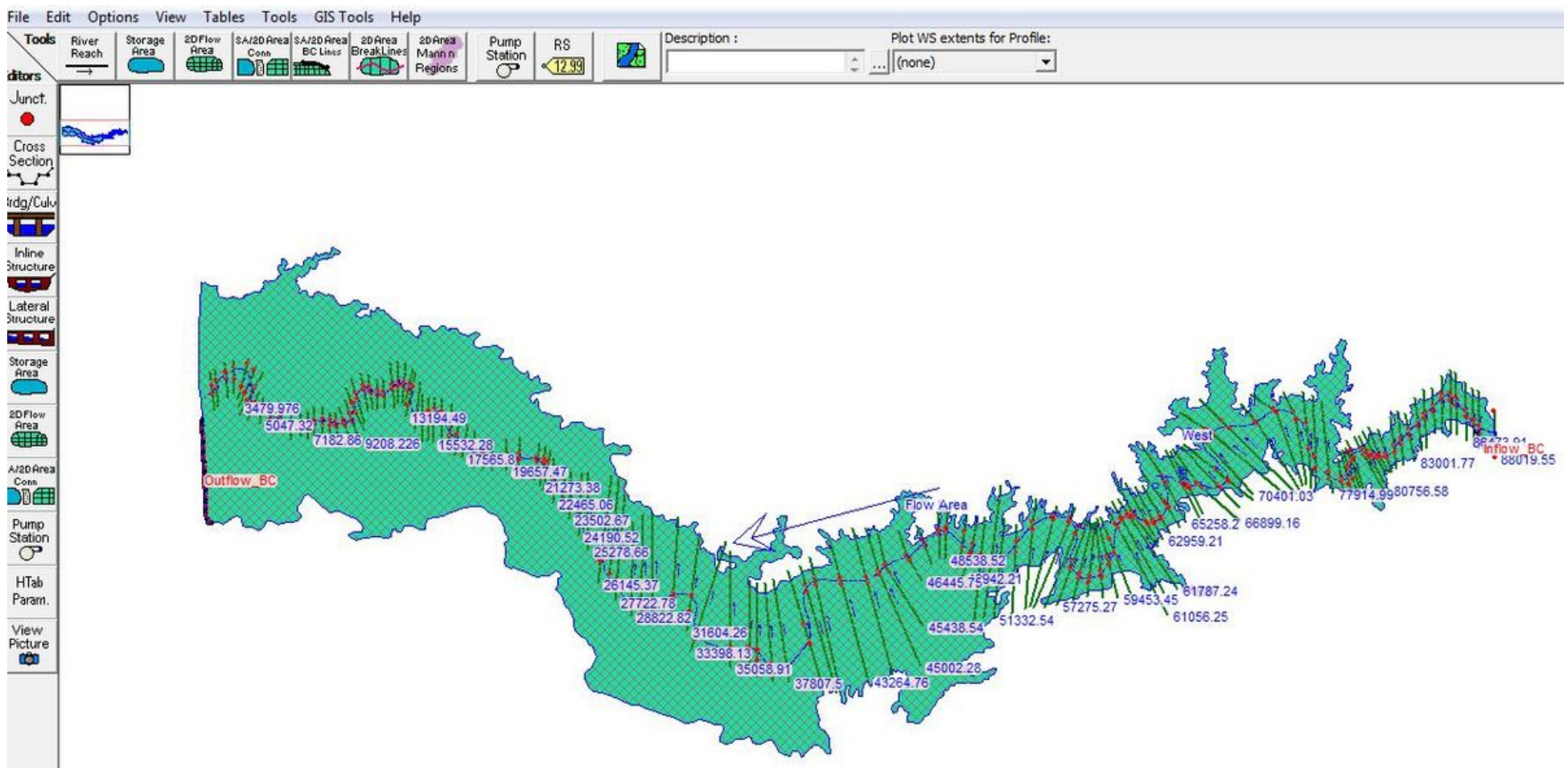

Figure 3 
The Baro river geometry map Note: The designations employed and the presentation of the material on this map do not imply the expression of any opinion whatsoever on the part of Research Square concerning the legal status of any country, territory, city or area or of its authorities, or concerning the delimitation of its frontiers or boundaries. This map has been provided by the authors.

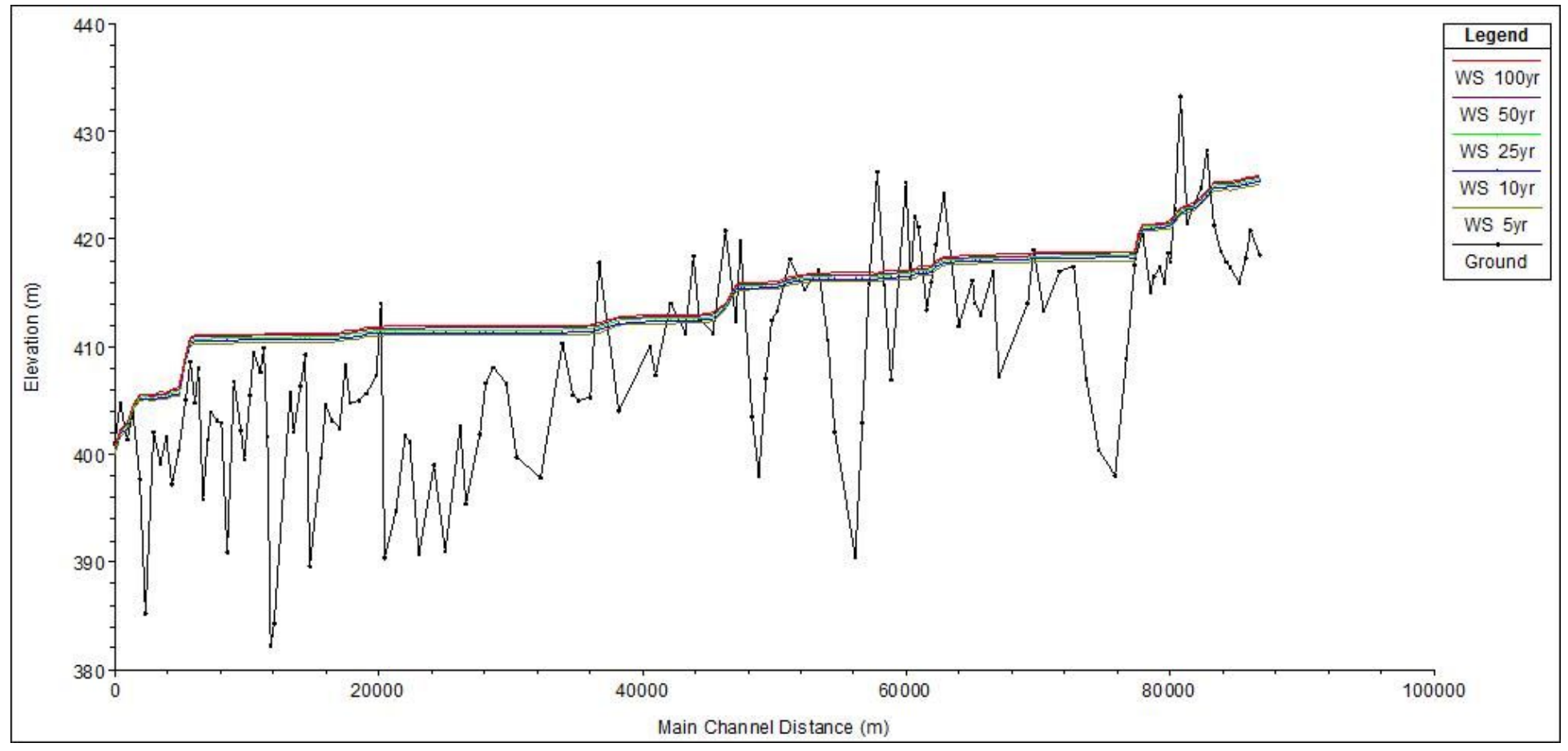

\section{Figure 4}

Water surface of different recurrence intervals obtained through HEC-RAS 

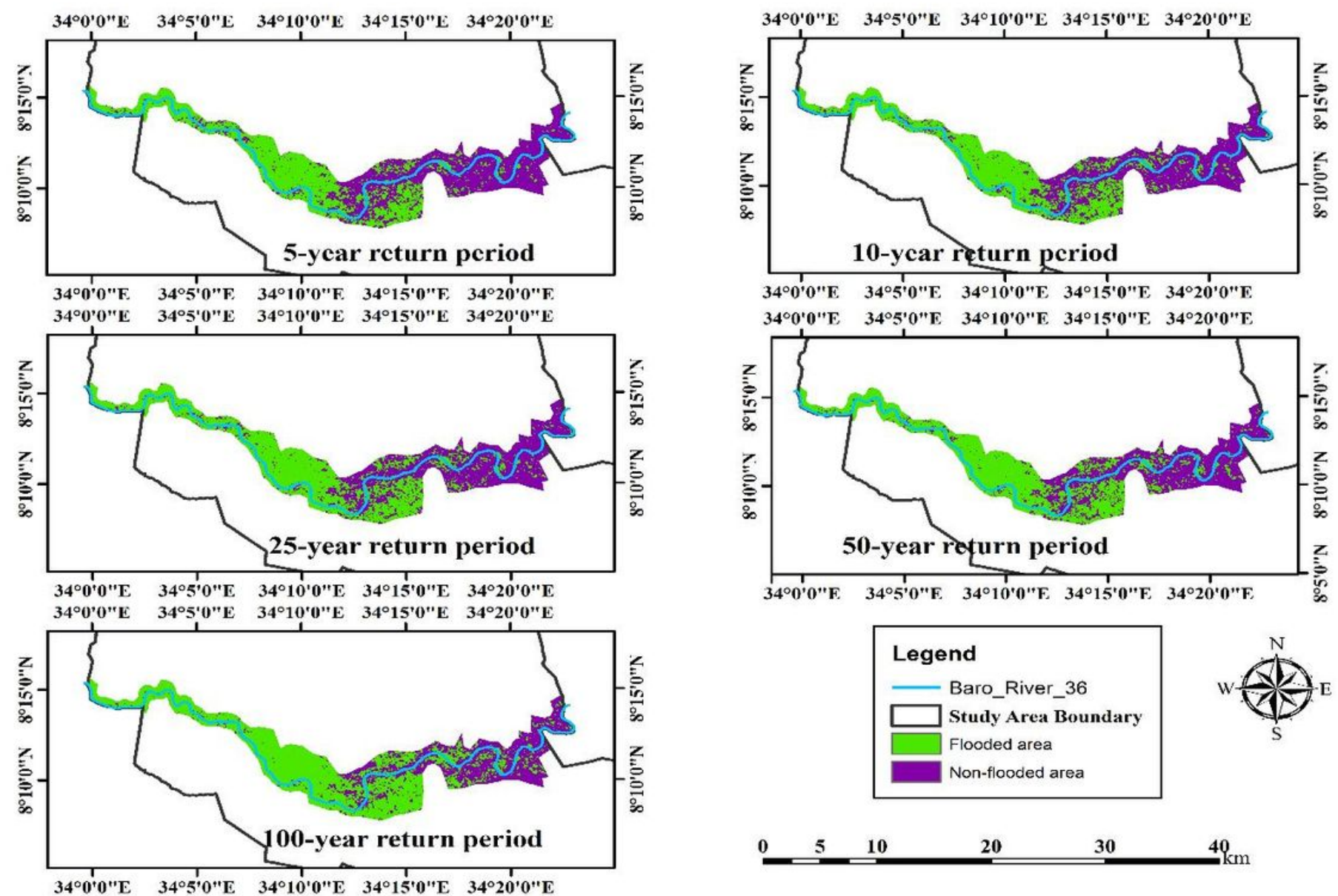

Figure 5

Flood inundation area of different recurrence intervals Note: The designations employed and the presentation of the material on this map do not imply the expression of any opinion whatsoever on the part of Research Square concerning the legal status of any country, territory, city or area or of its authorities, or concerning the delimitation of its frontiers or boundaries. This map has been provided by the authors. 

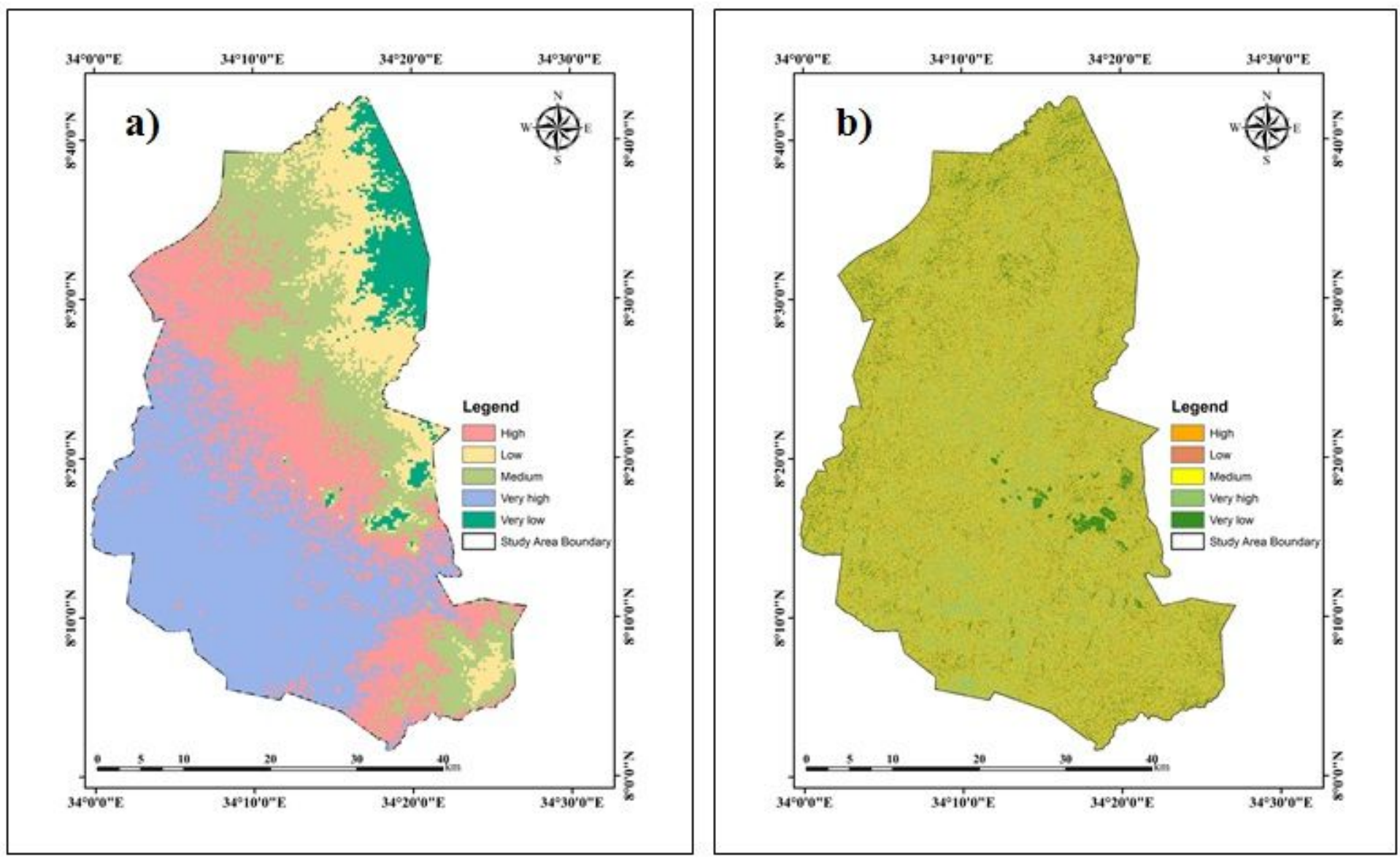

Figure 6

Reclassified maps (a) elevation and (b) slope Note: The designations employed and the presentation of the material on this map do not imply the expression of any opinion whatsoever on the part of Research Square concerning the legal status of any country, territory, city or area or of its authorities, or concerning the delimitation of its frontiers or boundaries. This map has been provided by the authors. 


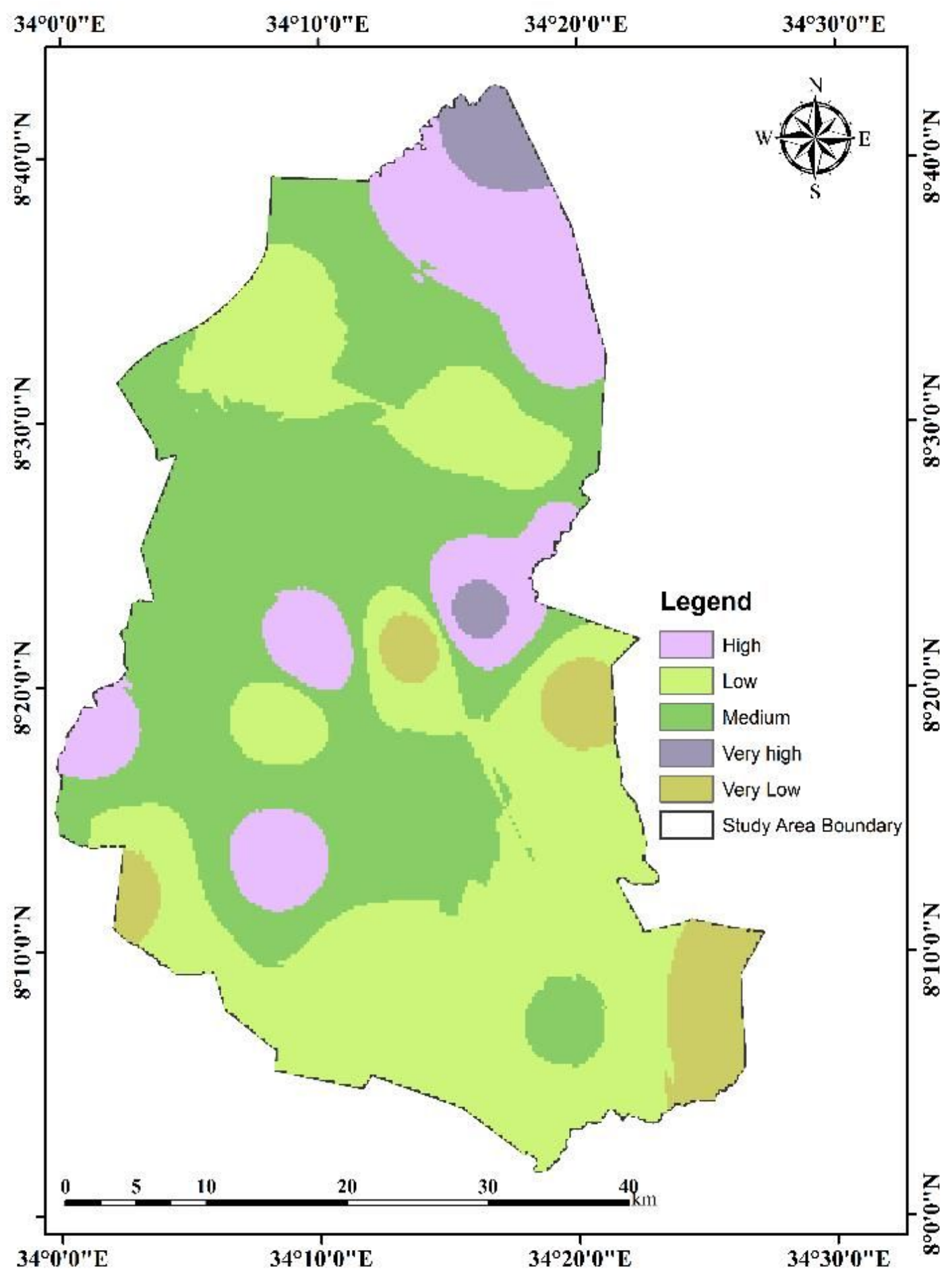

\section{Figure 7}

Reclassified rainfall map Note: The designations employed and the presentation of the material on this map do not imply the expression of any opinion whatsoever on the part of Research Square concerning the legal status of any country, territory, city or area or of its authorities, or concerning the delimitation of its frontiers or boundaries. This map has been provided by the authors. 

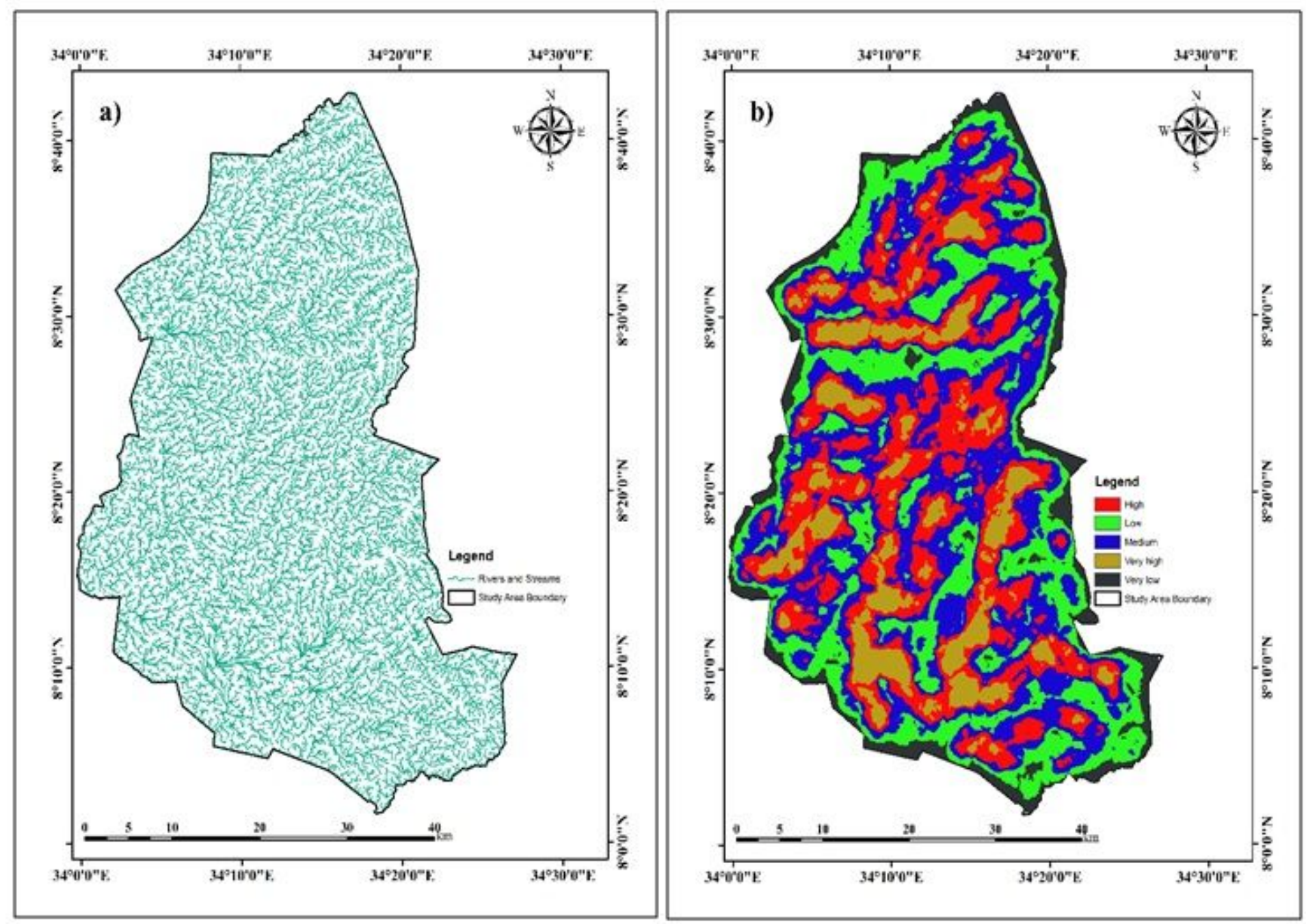

Figure 8

Drainage map (a), and reclassified drainage density map (b) Note: The designations employed and the presentation of the material on this map do not imply the expression of any opinion whatsoever on the part of Research Square concerning the legal status of any country, territory, city or area or of its authorities, or concerning the delimitation of its frontiers or boundaries. This map has been provided by the authors. 


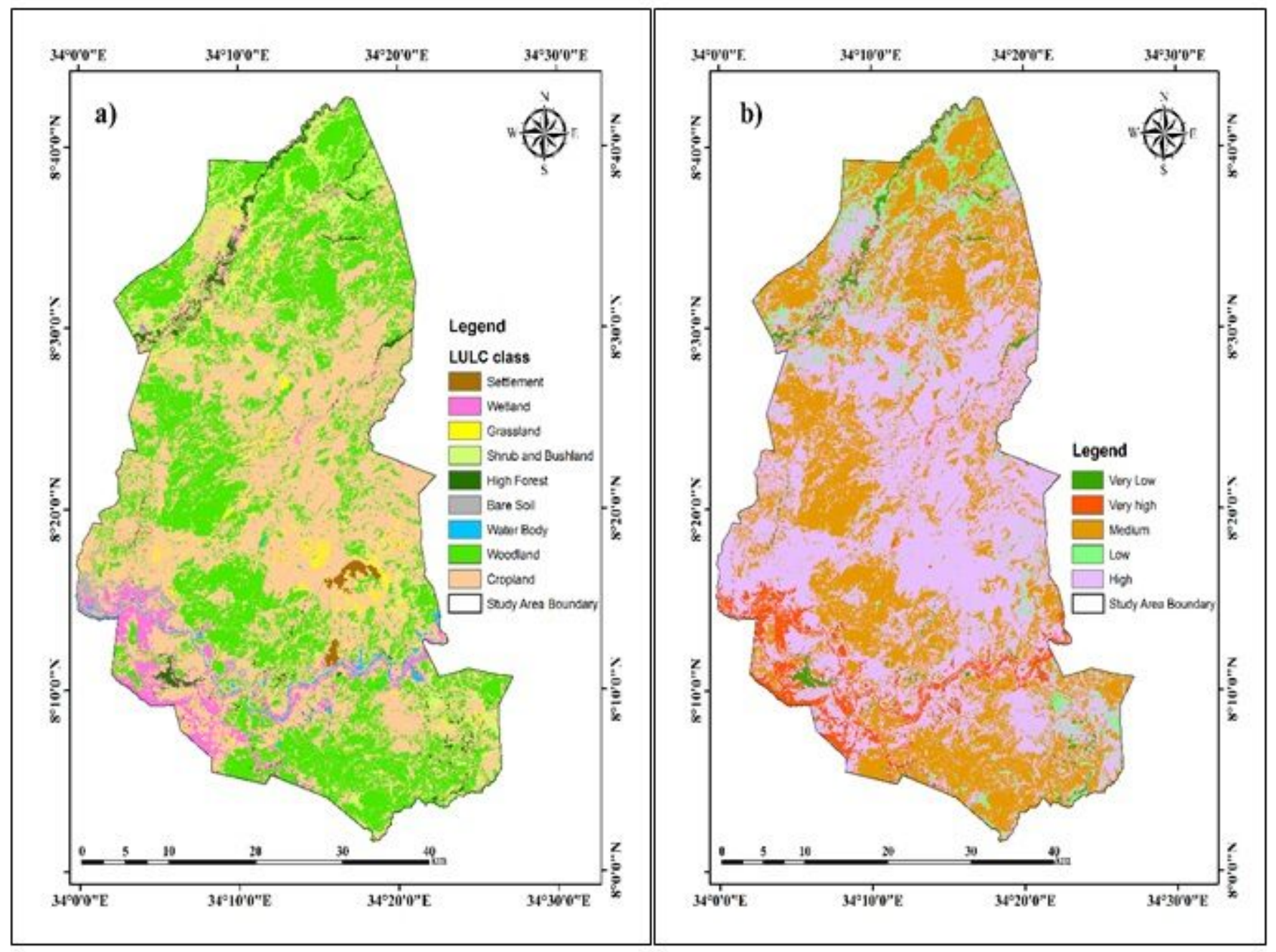

\section{Figure 9}

Land-use/land-cover map (a), and reclassified land-use/land-cover map (b) Note: The designations employed and the presentation of the material on this map do not imply the expression of any opinion whatsoever on the part of Research Square concerning the legal status of any country, territory, city or area or of its authorities, or concerning the delimitation of its frontiers or boundaries. This map has been provided by the authors. 


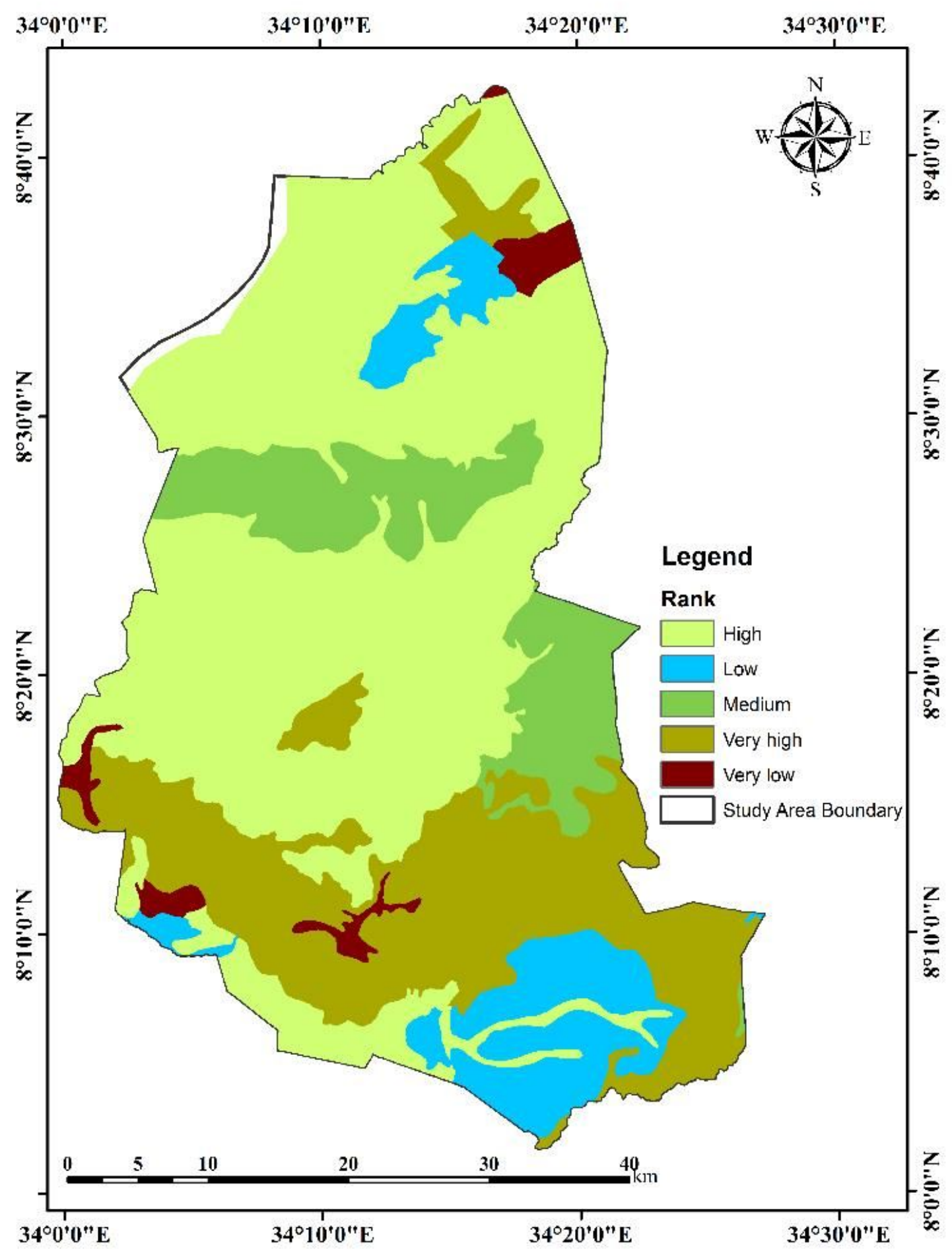

\section{Figure 10}

Reclassified soil map Note: The designations employed and the presentation of the material on this map do not imply the expression of any opinion whatsoever on the part of Research Square concerning the legal status of any country, territory, city or area or of its authorities, or concerning the delimitation of its frontiers or boundaries. This map has been provided by the authors. 


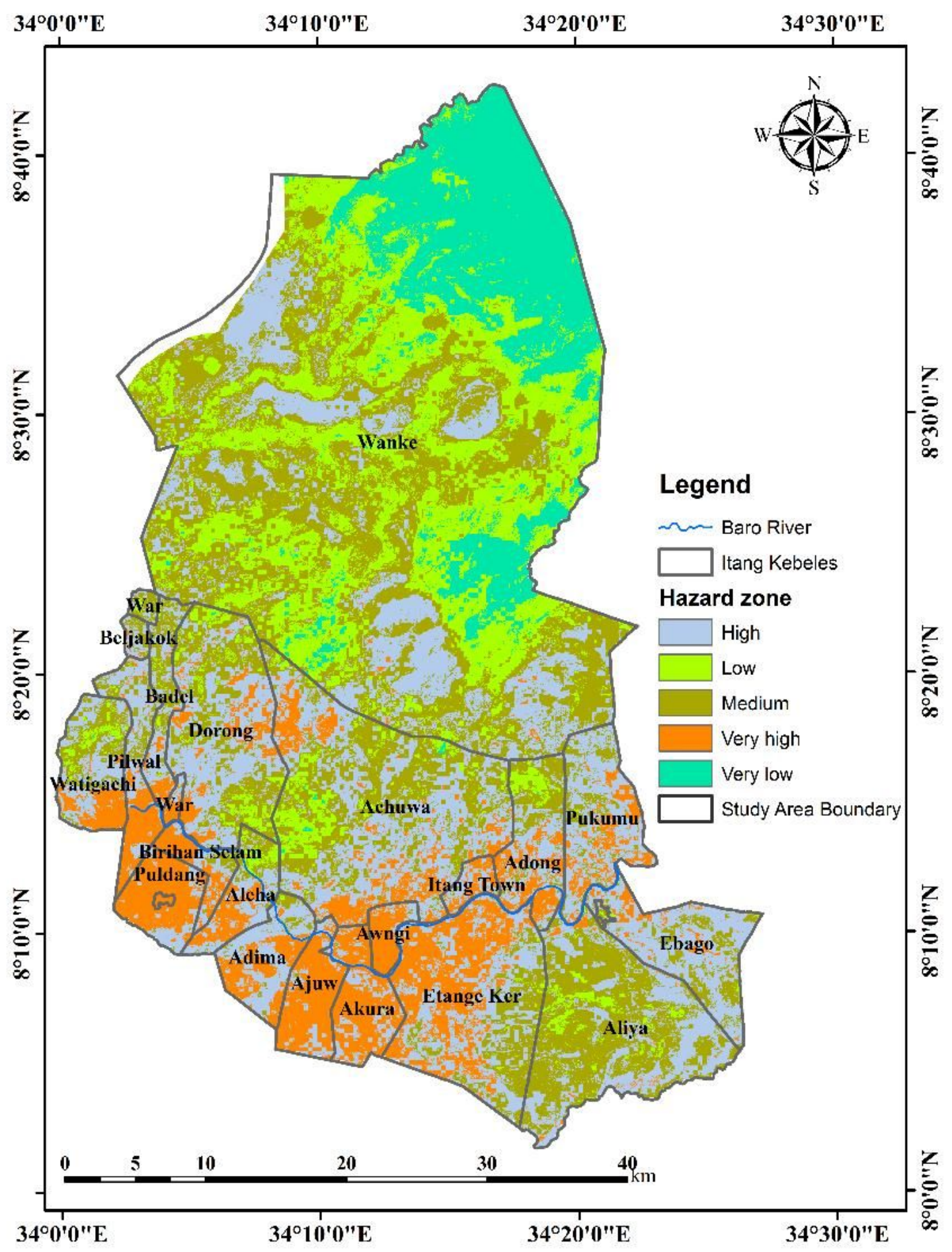

\section{Figure 11}

Flood hazard map Note: The designations employed and the presentation of the material on this map do not imply the expression of any opinion whatsoever on the part of Research Square concerning the legal status of any country, territory, city or area or of its authorities, or concerning the delimitation of its frontiers or boundaries. This map has been provided by the authors. 